\title{
Long term prognosis in yersinia arthritis: clinical and serological findings
}

\author{
J D Herrlinger, J-U Asmussen
}

\begin{abstract}
Twenty two patients were followed up for a mean of 10.7 years after acute yersinia arthritis. Their clinical course, agglutination antibodies, antibodies against plasmid coded yersinia proteins, and laboratory parameters of inflammation were analysed.

The clinical findings were unremarkable. Serum agglutinating antibodies against Yersinia enterocolitica were not found in any patient. Ten patients had no antibodies against plasmid coded bacterial proteins. Five patients showed IgG antibodies, one patient had an IgA and IgG result of questionable significance, and six patients had IgA and IgG antibodies in the immunoblot reaction. No evidence of systemic inflammation was found.

The persistence of $\mathrm{IgA}$ or IgG antibodies, or both, did not have a discernible influence on the clinical course. The development of erosive changes in the sacroiliac joints occurred independently of yersinia infection.
\end{abstract}

(Ann Rheum Dis 1992; 51: 1332-1334)

The clinical characteristics of acute yersinia arthritis are well known. Since the first descriptions in Finland, ${ }^{1-3}$ reports from other countries have also been published. ${ }^{4-6}$ The factors influencing the pathogenesis of yersinia arthritis are genetic disposition, ${ }^{7}$ possible persistence of the antigen in the synovia, 89 and antigen specific immunocomplexes in the circulation or in the synovia. ${ }^{10} 11$

In marked contrast to the abundant data on the acute phase of yersinia arthritis, only sparse information is available on its long term course and prognosis, and the bearing of immunological factors on them. To date, the only long term study was carried out in Scandinavia on a series of 129 patients for a mean observation time of 52 months (range 14-113). Eighty five of these patients were followed up for a further 10.5 years (range 6.3-16:8). ${ }^{12}$ According to these studies, the prognosis for patients with acute yersinia arthritis is highly favourable. In light of these data on long term prognosis, findings on the persistence of yersinia in intestinal mucosa and lymph nodes, ${ }^{13}$ on the persistence of antigens in the synovia, ${ }^{8}$ and on circulating immunocomplexes ${ }^{10}$ require critical evaluation to determine their implications for clinical diagnosis and prognosis in individual patients.

The data presented here describe the 10 year clinical course in 22 patients with acute reactive arthritis triggered by Yersinia enterocolitica infection and the kinetics of the agglutinating antibody titres during this period. In addition, serological findings using plasmid coded protein as antigen were examined.

\section{Patients and methods}

Twenty two patients diagnosed as having yersinia arthritis (serotype 3 or 9) were available for follow up after a mean of 10.7 years (range $8 \cdot 6-12 \cdot 6)$. Diagnosis was made according to the following criteria: $(a)$ at least one joint was painful and swollen for more than one week; $(b)$ antibodies against Yersinia enterocolitica were present; and, $(c)$ joint trauma, arthritis urica, rheumatoid arthritis, and other types of arthritis could be excluded.

In addition to a physical examination and questioning on the patient's history since infection, information on the following parameters was compiled: agglutinating antibodies against dead yersinia bacilli (Professor Dr Ullmann, Kiel); an enzyme linked immunosorbent assay (ELISA) against plasmid coded yersinia antigens (Professor Dr J Heesemann); ${ }^{14}$ radiographs of clinically affected joints; and laboratory parameters for inflammation (erythrocyte sedimentation rate, $\mathrm{C}$ reactive protein, iron, haematogram, total serum protein, serum protein electrophoresis, quantitative $\mathbf{I g G}$, $\operatorname{IgA}$, and $\operatorname{IgM}$ ).

\section{Results}

ACUTE PHASE

The mean age of the 22 patients (nine female, 13 male) was 35 years. Inflammation occurred chiefly in the weightbearing joints of the legs, about equally in the knee and ankle joints, followed by the interdigital joints of the feet. The only extra-articular symptom was erythema nodosum seen in two women and one man (all HLA-B27 negative). Sixteen patients were HLA-B27 positive (73\%). The table shows agglutination titres of serum samples against Yersinia enterocolitica, serotypes 3 and 9.

In patients with onset of symptoms not more than eight weeks before the physical examination, the mean erythrocyte sedimentation rate was $86 \mathrm{~mm}$ after one hour, the serum iron concentration was $8.0 \mu \mathrm{mol} / 1$, and the $\alpha_{2}$ globulin fraction in the serum protein electrophoresis was $12 \cdot 8 \%$

Radiological examination was not performed during the acute phase except on the sacroiliac joints in a single patient with marked limitation of lumbosacral spine mobility. A bilateral synostosis was found in this patient. 
Patient details, HLA-B27 status and Yersinia enterocolitica specific immunological reactivity of 22 patients with yersinia arthritis at the time of the acute disease and 10 years later

\begin{tabular}{|c|c|c|c|c|c|c|c|c|}
\hline \multirow[t]{3}{*}{$\begin{array}{l}\text { Patient } \\
\text { No. }\end{array}$} & \multirow[t]{3}{*}{ Date of birth } & \multirow[t]{3}{*}{ Sex } & \multicolumn{2}{|c|}{ Agglutinating antibodies } & \multicolumn{3}{|c|}{$\begin{array}{l}\text { Serum antibodies to } R P s^{*} \\
\text { lo years after acute disease }\end{array}$} & \multirow[t]{3}{*}{$\begin{array}{l}\text { HLA-B27 } \\
\text { status }\end{array}$} \\
\hline & & & \multirow[b]{2}{*}{ Acute disease } & \multirow{2}{*}{$\begin{array}{l}\text { After } \\
10 \text { years }\end{array}$} & \multirow{2}{*}{$\begin{array}{l}\text { ELISA } \\
I g G^{*}\end{array}$} & \multicolumn{2}{|c|}{ Immunoblot } & \\
\hline & & & & & & $I g A$ & $\operatorname{IgG}$ & \\
\hline \multirow[t]{2}{*}{$\begin{array}{l}1 \\
2\end{array}$} & \multirow[t]{2}{*}{$\begin{array}{l}16 \text { January } 1956 \\
21 \text { September } 1941\end{array}$} & \multirow[t]{2}{*}{$\begin{array}{l}\mathbf{M} \\
\mathbf{F}\end{array}$} & \multirow{23}{*}{$\begin{array}{l}\text { Y.e. } 0: 31: 1280+ \\
\text { Y.e. } 0: 31: 640 \\
\text { Y.e. } 0: 91: 640 \\
\text { Y.e. } 0: 31: 5120 \\
\text { Y.e. } 0: 31: 640 \\
\text { Y.e. } 0: 31: 5120 \\
\text { Y.e. } 0: 31: 10240 \\
\text { Y.e. } 0: 91: 80 \\
\text { Y.e. } 0: 31: 2560 \\
\text { Y.e. } 0: 31: 160 \\
\text { Y.e. } 0: 31: 160 \\
\text { Y.e. } 0: 91: 160 \\
\text { Y.e. } 0: 31: 640 \\
\text { Y.e. } 0: 31: 1280 \\
\text { Y.e. } 0: 31: 5120 \\
\text { Y.e. } 0: 31: 640 \\
\text { Y.e. } 0: 91: 640 \\
\text { Y.e. } 0: 31: 640 \\
\text { Y.e. } 0: 31: 2650 \\
\text { Y.e. } 0: 91: 160 \\
\text { Y.e. } 0: 31: 1280 \\
\text { Y.e. } 0: 31: 640 \\
\text { Y.e. } 0: 91: 80 \\
\text { Y.e. } 0: 31: 40 \\
\text { Y.e. } 0: 31: 1280 \\
\text { Y.e. } 0: 91: 5120 \\
\text { Y.e. } 0: 91: 640\end{array}$} & - & - & + & + & + \\
\hline & & & & - & - & $(+)$ & + & + \\
\hline 3 & 5 June 1939 & $\mathbf{M}$ & & - & - & - & + & + \\
\hline 4 & 25 February 1941 & $\mathbf{M}$ & & - & - & $(+)$ & $(+)$ & + \\
\hline 5 & 24 April 1910 & $\mathbf{M}$ & & - & - & - & - & - \\
\hline 6 & 31 December 1922 & $\mathbf{F}$ & & - & - & + & + & - \\
\hline 7 & 18 June 1951 & $\mathbf{F}$ & & - & - & - & - & + \\
\hline 8 & 2 January 1951 & $\mathbf{M}$ & & - & + & + & + & + \\
\hline 9 & 19 October 1963 & $\mathbf{M}$ & & - & - & - & - & + \\
\hline \multirow[t]{2}{*}{10} & \multirow[t]{2}{*}{18 July 1941} & \multirow[t]{2}{*}{ M } & & & & & & \\
\hline & & & & - & + & + & + & - \\
\hline $\begin{array}{l}11 \\
12\end{array}$ & 15 August 1933 & $M$ & & - & - & - & - & + \\
\hline $\begin{array}{l}12 \\
13\end{array}$ & 6 June 1943 & $\mathbf{F}$ & & - & - & - & - & - \\
\hline \multirow{2}{*}{14} & \multirow{2}{*}{$\begin{array}{l}31 \text { July } 1934 \\
10 \text { December } 1951\end{array}$} & $\mathbf{F}$ & & - & - & - & - & - \\
\hline & & $\Gamma$ & & - & $(+)$ & + & + & + \\
\hline \multirow{2}{*}{$\begin{array}{l}15 \\
16\end{array}$} & \multirow{2}{*}{$\begin{array}{l}4 \text { October } 1937 \\
8 \text { September } 1939\end{array}$} & \multirow{2}{*}{$\begin{array}{l}\mathbf{M} \\
\mathbf{M}\end{array}$} & & - & - & - & - & + \\
\hline & & & & - & - & - & - & - \\
\hline \multirow{2}{*}{$\begin{array}{l}17 \\
18\end{array}$} & \multirow{2}{*}{$\begin{array}{l}7 \text { September } 1952 \\
7 \text { June } 1948\end{array}$} & \multirow{2}{*}{$\begin{array}{l}\mathbf{M} \\
\mathbf{F}\end{array}$} & & - & $(+)$ & + & + & + \\
\hline & & & & - & - & - & + & + \\
\hline 19 & 13 February 1958 & $\mathbf{F}$ & & - & - & - & - & + \\
\hline 20 & 20 June 1947 & $\mathrm{~F}$ & & - & $(+)$ & - & + & + \\
\hline 21 & 3 July 1951 & M & & - & - & - & - & + \\
\hline 22 & 17 November 1938 & $\mathbf{M}$ & & & + & $(+)$ & + & + \\
\hline
\end{tabular}

${ }^{*} \mathrm{RPs}=$ plasmid encoded released proteins; $\mathrm{ELISA}=$ enzyme linked immunosorbent assay. $\dagger$ Y.e. 0:3/0:9=Yersinia enterocolitica serotype 0:3/0:9.

FOLLOW UP

Intervening history, clinical, and radiological findings

The acute disease lasted from one month to one year. The male patient with synostosis of the sacroiliac joints developed the clinical characteristics of severe ankylosing spondylitis and is not included in the following overview. Of the remaining 21 patients, seven did not have rheumatic disorders at follow up. Five patients had slightly restricted mobility in their peripheral joints, (two in the hip, one in the knee, one in a shoulder joint, and one in the interdigital joints). Three patients reported arthralgias without clinically important findings.

Three patients reported pain in the cervical spine. Only two showed a slight restriction of function. The thoracic spine was normal in all patients.

Ten patients had occasional lower back pain that increased under mechanical strain. Radiographs were not available for three of these patients. Six patients had radiologically normal spinal and sacroiliac joints with age related degenerative changes. One female patient (HLA-B27 positive), who had ischialgia-like back pain once or twice a year, had the radiological characteristics of sacroiliitis and symphysitis. At follow up her clinical findings were normal. One male patient, also HLA-B27 positive, had painless, unremarkable clinical findings with the radiological characteristics of a unilateral, discrete sacroiliitis in the lower sector. Radiological examination was not performed in five patients with uneventful intervening histories and no symptoms at follow up. In the remaining patients radiological examination only showed signs of spondylosis.

Agglutinating antibodies

In all 22 patients agglutinating antibodies for
Yersinia enterocolitica, serotype 3 or 9, were negative.

\section{Antibodies against plasmid coded bacterial proteins} and immunoblot studies

In 10 patients neither antibodies of class $\operatorname{IgA}$ (ELISA) nor IgA and IgG antibodies (immunoblot) against plasmid coded yersinia antigens could be seen. The immunoblot reaction in five patients showed IgG antibodies. IgA antibodies were not found and the ELISA for IgG antibodies was negative. One patient had borderline significant IgA and IgG bands. The serological findings in this patient were unclear.

In six patients an immunoblot for $\operatorname{IgA}$ and IgG was positive due to a recent or existing yersiniosis. Three of these serum samples showed additional IgG antibodies in an ELISA. All serological findings are given in the table.

\section{Unspecific inflammatory parameters}

Laboratory signs of inflammation were not present at follow up in all 22 patients. The mean erythrocyte sedimentation rate was $7 \mathrm{~mm}$ after one hour, the serum iron concentration was $14.9 \mu \mathrm{mol} / 1$, and the $\alpha_{2}$ fraction in serum protein electrophoresis was $7 \cdot 7 \%$. The $C$ reactive protein concentration was less than $5 \mathrm{mg} / \mathrm{l}$ in all patients.

\section{Discussion}

Twenty two patients were followed up for a mean of 10 years after acute yersinia arthritis. Physical and radiological examinations were performed and a detailed history of characteristics since infection compiled. In addition, laboratory tests were performed on inflammatory parameters and serum yersinia specific immuno- 
logical reactivity using agglutination antibody reactions and immunoblot and ELISA procedures. ${ }^{14}$

In a similar manner to the comparable follow up study in Finland, ${ }^{12}$ we found an excellent long term prognosis for clinical outcome. Persistent, frankly inflammatory joint changes did not occur in any of our patients.

Two patients (patients 3 and 20), who were HLA-B27 positive, had radiological signs of an incipient sacroiliitis at follow up. Clinical findings on the sacroiliac joints were unremarkable in these two patients. IgA antibodies against plasmid coded yersinia proteins could not be seen; IgG antibodies were present in the two patients.

Of the remaining 19 patients, none showed clinically inflamed joint changes or radiological evidence of inflammatory changes. Twelve patients showed clinical or radiological signs, or both, of osteoarthrosis and spondylosis that did not exceed normal results for the appropriate age or occupation.

In the study performed in Finland, ${ }^{12} 51 \cdot 8 \%$ of patients had 'some joint symptoms' during the follow up period. A more detailed evaluation was not performed. In $45.9 \%$ of their patients symptoms were 'mild and transient'. Only five patients $(5 \cdot 9 \%)$ had chronic joint disorders, and three of the five had already experienced arthritic symptoms before the yersinia infection. One patient developed chronic Reiter's disease and another a chronic seronegative polyarthritis.

In light of the favourable prognosis for yersinia arthritis also found in this study, the serological data require critical evaluation. In five of our 22 patients specific IgA antibodies were positive; in a further three patients $(36 \%)$ they were weakly positive. This finding correlates with neither the clinical course nor the HLAB27 status. Twelve patients (54\%) had IgG antibodies. All patients with IgA also had IgG antibodies. There was no discernible correlation between positive IgG antibodies and HLA-B27 status. IgA antibodies were negative in three patients with inflammatory changes in the sacroiliac joints. The persistence of IgA or IgG antibodies, or both, against virulence associated yersinia antigens was without discernible influence on the long term prognosis.

The development of erosive changes in joints occurs in HLA-B27 positive subjects independent of yersinia. The three patients with radiological evidence of bone changes had no yersinia specific IgA antibodies. Erosive or sclerotic changes, or both, in joints or tendon attachments due to ankylosing spondylitis in one patient or an isolated sacroiliitis in two other patients developed independently of bacterial infection. Hence the interdependence is only apparent, attributable to the close, but unrelated, association of the two phenomena with HLA-B27.

1 Ahvonen P, Sievers K, Aho K. Arthritis associated with Yersinia enterocolitica infection. Acta Rheumatol Scand 1969; 15: 232-53.

2 Ahvonen $P$. Human yersiniosis in Finland. II. Clinica features. Ann Clin Res 1972; 4: 39-48.

3 Winblad S. Arthritis associated with Yersinia enterocolitica infections. Scand $\mathcal{F}$ Infect Dis 1975; 77: 191-5.

4 Herrlinger J D, Wuthe $\mathrm{H} \mathrm{H}$. Yersinia arthritis. Med Klin 1979; 74: $1681-5$.

5 Chalmers A, Kaprove R E, Reynolds W J, et al. Postdiarrheal arthropathy of yersinia pseudotuberculosis. Can Med arthropathy of yersinia

6 Sheldon P J, Pell P. Yersinia arthritis in the Midlands: clinical and immunological features in ten cases during 1980-1983. Br F Rheumatol Suppl 1983; 22: 46-9.

7 Aho K, Ahvonen P, Lassus A, Sievers K, Tiilikainen A. HL-A 27 in reactive arthritis: a study of yersinia arthritis and Reiter's disease. Arthritis Rheum 1974; 17: 521-6.

8 Merilahti-Palo R, Söderström K-O, Lahesmaa-Rantala R Granfors $\mathrm{K}$, Toivanen A. Bacterial antigens in synovia biopsy specimens in yersinia-triggered reactive arthritis. Ann Rheum Dis 1991; 50: 81-90.

9 Heesemann J, Gaede $K$. Mechanisms involved in the pathogenesis of yersinia infections. Rheumatol Int 1989; 9: 213-7.

10 Lahesmaa-Rantala R, Granfors K, Kekomäki R, Toivanen A Circulating yersinia specific immune complexes after acute yersiniosis: a follow-up study of patients with and without yersiniosis: a follow-up study of patients with and with
reactive arthritis. Ann Rheum Dis 1987; 46: 121-6.

11 Lahesmaa-Rantala R, Granfors K, Isomäki H, Toivanen A Lahesmaa-Rantala $\mathbf{R}$, Granfors $\mathrm{K}$, Isomäki $\mathrm{H}$, Toivanen $A$.
Yersinia-specific immune complexes in the synovial fluid of patients with yersinia-triggered reactive arthritis. Ann Rheum Dis 1987; 46: 510-4.

12 Leirisalo-Repo M, Skoranta $\mathbf{H}$. Ten-year follow-up study of patients with yersinia arthritis. Arthritis Rheum 1988; 31 533-7.

13 DeKoning J, Heesemann J, Hoogkamp-Korstanje J A A, $e$ $a l$. Yersinia in intestinal biopsy specimens from patients with seronegative spondylarthropathy: correlation with specific IgA antibodies. F Infect Dis 1989; 159: 109-12.

14 Heesemann J, Gross U, Schmidt N, Laufs R. Immunological analysis of plasmid-encoded proteins released by enteropathogenic yersinia species grown in calcium-deficient pathogenic yersinia species grown
media. Infect Immun 1986; 54: 561-7. 